UDC 81'23: 811.161.2

DOI https://doi.org/10.32838/2663-6069/2020.4-1/16

Lokota I. M.

Odesa I. I. Mechnikov National University

\title{
ASSOCIATION AS A DIAGNOSTIC CRITERION FOR PARANOID SCHIZOPHRENIA
}

Scientists have proven that schizophrenia disorders are found at all levels of language organization: phonetic, semantic, and grammatical. Some levels help to distinguish between mentally ill and healthy people and can also separate patients with schizophrenia from patients with other mental illnesses. Therefore, it is necessary to deeply explore the languages of such patients and explain its deep psycho- and neurolinguistic mechanisms related to the processes of associations.

The article describes the results of an associative experiment conducted with individuals diagnosed with "paranoid schizophrenia" and mentally healthy people. The purpose of this article is to identify the characteristics of the associative background of people diagnosed with "paranoid schizophrenia". The obtained reactions are classified according to the logic of the combination of stimulus words and reaction words (logical and peripheral), as well as according to their grammatical characteristics (syntagmatic and paradigmatic). Interpretation of the obtained results is presented in stages. We conducted a comparative analysis of the reactions of two groups of respondents - mentally ill and healthy women.

It is established that the peculiarities of the association of mentally healthy and mentally ill women differ in grammatical criteria and the logic (content) of the connection between the word-stimulus and reactions. The free flow of associations reveals the personal experiences of patients. Some patients refused to participate in the experiment and had an unusual reaction to words-stimuli, which can be manifested in grunting, complaints, exclamations, manifestations of autonomic emotions, the pronunciation of unnecessary or inappropriate word-reaction, etc.

Characteristics of speech in schizophrenia is a complex and ambiguous issue, the study of which should be done to facilitate the diagnosis of the disease. Further prospects of the study are related to the analysis of the peculiarities of speech and association in disorders of higher mental functions: Parkinson's disease, Alzheimer's disease, etc.

Key words: schizophrenia, paranoid schizophrenia, associations, associative experiment.

Formulation of the problem. Schizophrenia is a mental disorder (or group of mental disorders) characterized by the breakdown of thought processes, emotions, and behavior [19]. According to the characteristics of clinical manifestations (symptoms and syndromes), there are 4 main forms of schizophrenia (simple, paranoid, hebephrenic, and catatonic) [16], each form has its own characteristics of the manifestation and course of the disease. Paranoid schizophrenia (60-80\% of all cases of schizophrenia) is the most frequently diagnosed in all countries of the world [16]. According to the International Classification of Diseases, this form of schizophrenia has the following clinical diagnostic criteria:

1) delusional ideas of persecution, relationship problems, overvalued ideas of guilt, persecution, reference, and religiosity;

2) auditory true and pseudo-hallucinations;

3) disrupt normal daily activities, tactile, and visual hallucinations [16].
It should also be noted that the speech of schizophrenics is significantly different from the speech of mentally healthy people [1]. Research of the communication disorders in schizophrenia have been conducted since the separation of schizophrenia as an independent disease [18;21]. During this time, there were different approaches to interpreting the characteristics and nature of schizophrenia: from the identification of speech and thinking disorders $[12 ; 18 ; 21]$ to a comprehensive analysis of the actual speech of the patients [9]. The importance of these studies is provided by the presence in modern classifications of mental illness of such diagnostic criteria as an incoherence of speech, a sharp transition from one topic to another, answers that are not focused on the interlocutor, etc. $[10 ; 17]$.

Scientists have proved that schizophrenia disorders are detected at all levels of language organization: phonetic, semantic, and grammatical (T. Ahutina, A. Leont'ev, A. Lurija, L. Saharnyj and others). Some levels can not only differentiate mentally ill people 
and healthy people but also they allow scientists to separate patients with schizophrenia from patients with other mental illnesses, which determines the need for in-depth study of the speech of such patients and an explanation of its deep psychoand neurolinguistic mechanisms, which are very closely related to the processes of associations.

Analysis of recent research and publications. The first attempts to use associations to study psychological problems date back to the second half of the nineteenth century. Thus, W. Wundt tried to reconstruct the mechanisms of thinking through the analysis of the speed of associative reactions; S. Freud used free associations in order to penetrate the subconsciousness of his clients; G. Ebbinghaus used an associative experiment to study the characteristics of memory; E. Kraepelin used this method as a clinical and diagnostic tool in psychiatric practice.

One of the greatest contributions to the development of the procedure and criteria for interpreting the data of the associative experiment belongs to K. Jung, who sought to prove that clients with similar problems will have close groups of associations. However, in the course of research he found a number of nonspecific reactions, so-called artifacts, which are still widely used in the analysis: prolonged reaction time, misunderstanding of the stimulus, repetition of stimulus words by the researcher, lack of reactions, stuttering, and others. K. Jung considered his associative experiments as a diagnostic tool of psychotherapeutic work, but did not deny their actual therapeutic effect; yes, he analyzed the received material together with the clients, discussing characteristics of reactions and their maintenance.

In domestic psychology, A. Lurija was actively developing an associative experiment [9]. The scientist modified the procedure by proposing a related motor technique - a prototype polygraph (lie detector). Thus, together with the verbal reaction, the test subject had to press the pneumatic buttons with both hands. As a result of the analysis of speech and motor reactions (latent period of speech response, form, and duration of motor response) it was possible to make a conclusion about the change in the emotional state of the subject "hidden consequences of affect". This technique has been used in forensic and psychiatric practice.

In modern psychological research, the associative experiment is widely used to analyze the age patterns of speech development; the semantic structure of consciousness; associative memory; features, including pathologies of thinking and even to analyze the involvement of a person in a criminal activity
(O. Zalevska, E. Tarasov, O. Ghoroshko, M. Patsys, T. Kovalevska, N. Kutuza and others).

Today there is only generalized information about the peculiarities of the association of patients with schizophrenia, therefore, this problem requires detailed study and is relevant.

The purpose of this article is to identify the characteristics of the associative background of people diagnosed with "paranoid schizophrenia", which is realized through the solution of the following tasks:

- development and conduct of an associative experiment among mentally ill and healthy people;

- selection of stimulus words based on which the associative experiment was conducted;

- stablishing characteristic differences between the associative background of mentally healthy people and the associative background of schizophrenics.

The object of research: the speech produced by schizophrenia patients

The subject of research: characteristics of association of patients diagnosed with "paranoid schizophrenia".

In the process of research, we used both general and special methods. As general scientific methods we use a method of observation, which was used to collect factual material; a quantitative method that helped to establish the number of cases showing violations at different levels of language; descriptive, which is based on the implementation of the general characteristics of the collected material add; analysis and synthesis, which was used systematized and generalized the results. Among the special ones is the method of associative experiment, which helped to trace the dynamics of associative connections in the mind of a sick person and component analysis, with the help of which the semantic characteristics of words were research.

Research material. The total number of reactions of mentally ill women - 174 and the total number of reactions of mentally healthy women -7246 .

In the future, we plan to conduct an associative experiment with men with schizophrenia.

All respondents were of different ages, education, and social status, which allowed for more objective information about the course of the disease. Eleven women diagnosed with paranoid schizophrenia and the control group is represented by 50 mentally healthy women.

Scientific novelty of the research - the associative experiment was conducted among people with paranoid schizophrenia, an associative background of perception of certain words-stimuli by patients was established, characteristic differences between the associative background of mentally healthy people 
and patients diagnosed with "paranoid schizophrenia" were revealed.

Theoretical and practical value - the conclusions that were drawn during the study can be used in the further development of this topic. They can serve as a basis for in-depth study of speech characteristics of the patients with schizophrenia at different stages, and the results can be used to develop a more detailed theory of pathopsycholinguistics, altered states of consciousness, etc. The results can help to develop methods for speech correction recognition of diseases at the initial stage.

Association (from the latin. Associatio - connection) - a natural connection that arises in the process of thinking between the elements of the psyche, as a result of which the appearance of one element in certain conditions causes the image of another associated with it. It is a connection between individual phenomena, facts or objects that are reflected in consciousness and fixed in memory. Associationism the explanation of mental processes using the principle of association: complex mental formations are secondary and arise from the simplest elements through their associations [11, pp. 55-56].

In psycholinguistics, there are several ways to classify associations. For example, D. Terekhova and L. Kushmar distinguish such types of reactions as paradigmatic, syntagmatic, thematic, grammatical, word-forming, phonetic, reminiscent [13], and others. In our study, the classification is based on the logic of their combination (logical and peripheral) L. Zaselina [5], and the grammatical characteristics of stimulus words and reaction words (syntagmatic and paradigmatic) by A. Lurija [9].

The stimulus for the experiment was the following list of the words: мати (verb), говорити, любити, чоловік, жінка, дитина, небо, море, молитва, червоний and зелений. The following list of words was chosen because:

1. Words belong to different parts of the speech;

2. Mostly all words are emotionally colored, which helps to get more associations and trace the expression of assessments of phenomena from the point of view of the speaker (for example: «жінка» or «молитва»)). Also, such words-stimuli are associated with personal perception, which can evoke emotional, event-related memories;

3. These words are well-known and most frequent in the colloquial style of the modern Ukrainian language [3], they are not abstract, foreign, terms, and do not need explanation.

The experiment consisted of three stages. At the first stage, a study was conducted among mentally healthy women, at the second - among mentally ill ones. The third stage was to analyze the associative background of both groups and compare the results.

In our study, we prefer the oral form of the experiment, which has certain time constraints and helps to identify spontaneous associations, while in written form there are factors that make the spontaneous response more complicated. A. Lurija notes that "oral expression is based on a large number of non-verbal factors of communication (knowledge of the situation, gestures, facial expressions, intonation) and all these are not present in the written statement" [8, p. 288].

The material was previously recorded on audio (dictation machine), decoded, and processed into a format accessible for reading and analysis.

After performing the associative experiment, we consistently compared the stimulus-response pairs in two categories: logical (central and peripheral) and grammatical (syntagmatic and paradigmatic) reactions. According to V. Beljanin, "Syntagmatic associations are called that ones, the grammatical class of which differs from the grammatical class of the word-stimulus. Paradigmatic associations are reactions of the same grammatical class as the word stimulus" [1].

If there was a logical connection between the word-stimulus and the association, then we put a mark in the column "central logical reaction". There are 6789 such associations, which is $79.89 \%$ of the total number of mentally healthy women, and 29 , respectively, which is $16.67 \%$ of mentally ill women.

For example, we got the reactions of mentally healthy women to the word: «зелений»- трава (49), колір (48), дерево (44), ліс (40), огірок (35), очі (31), листя (28), крокодил (24), чай (20), рослина (14), яблуко (9), квітка (8), петрушка (4), кріп (3), дитинство, радість, улюблений колір мами, ycnix. All reactions, except дитинство, радість, улюблений колір мами, belong to the central logical reactions.

On the same word, we received reactions of mentally ill women: «зелений» - трава (2), привабливий, усе оживає, надійний, можна йти пішоходам, колір. All reactions, except трава, колір, belong to the peripheral logical reaction.

If the connection between the stimulus and the reaction was not detected, the pair belonged to the column "peripheral logical reaction". There are 1457 number of such units, which is equal to $20.11 \%$ of mentally healthy women, and 145 , which is $83.33 \%$ of women diagnosed with "paranoid schizophrenia". 


\begin{tabular}{|c|c|c|}
\hline \multirow{2}{*}{ respondent } & \multicolumn{2}{|c|}{ logical connection } \\
\cline { 2 - 3 } & $\begin{array}{c}\text { central logical } \\
\text { reaction }\end{array}$ & $\begin{array}{c}\text { peripheral logical } \\
\text { reaction }\end{array}$ \\
\hline $\begin{array}{c}\text { mentally } \\
\text { healthy }\end{array}$ & $79.89 \%$ & $20.11 \%$ \\
\hline mentally ill & $16.67 \%$ & $83.33 \%$ \\
\hline
\end{tabular}

The data obtained shows that thinking of mentally healthy women is dominated by central logical reactions. This indicates the development of mental processes, cognitive sphere, and level of thinking of most respondents.

Among women diagnosed with "paranoid schizophrenia", a significant proportion of responses belong to peripheral logical reactions, which indicates the probable rigidity of speech and thought processes.

\begin{tabular}{|c|c|c|}
\hline \multirow{2}{*}{ respondent } & \multicolumn{2}{|c|}{ Grammatical connection } \\
\cline { 2 - 3 } & syntagmatic & paradigmatic \\
\hline $\begin{array}{c}\text { mentally } \\
\text { healthy }\end{array}$ & $68 \%$ & $32 \%$ \\
\hline mentally ill & $39.66 \%$ & $60.34 \%$ \\
\hline
\end{tabular}

According to the grammatical criterion, the group characterized by the syntagmatic connection included 5050 associations of mentally healthy women. This means that in the recorded reactions there was a connection between different grammatical categories of words, exactly: between nouns and adjectives, verbs and nouns, nouns and adverbs, verbs and adverbs (for example: говорити - слова, любити - маму, небо блактине, etc.). The number of reactions according to the syntagmatic variant of communication is equal to $68 \%$. The group, characterized by a paradigmatic connection, includes 2376 wordsreactions to the proposed words-stimuli, which is $32 \%$ of the total. Such answers revealed a connection within one grammatical category (for example: говорити - сказати, жінка - чоловік, небо - соние, etc.). The increase in syntagmatic reactions indicates the complexity of thinking, the ability of the respondent to identify similar objects, and their features. Such thinking is characterized by syncretism, complexity, when the object or feature is presented together with the accessories that complement them [9].

It also should be noted that the number of reactions to the stimulus among mentally healthy women is greater than among women with "paranoid schizophrenia": 6-8 words and 3-4 words, respectively, indicating a decrease in the verbal activity of patients.
In 4 cases it was impossible to trace the chain of logical transitions of patients, for example, as in the following example: «Жінка - пару копійок попросити, яка народила». Here we can observe the rupture of associations and the lack of logical connection.

We noticed that patients often described objects around them, after the researcher's remark said the words very slowly, and were asking questions that were not related to the experiment, such as: $« B u$ одружений?». 2 reactions of this type were recorded.

Some patients refused to participate in the experiment because they were in a state of anxiety and delirium and did not want to have any contact, which is a characteristic feature of this disease [16].

Among the patients diagnosed with "paranoid schizophrenia" words-stimuli more often were associated with a negative experience. Yes, a patient who was beaten at home by her husband, at the word "husband" brings up a reaction «бити по головi, кулаки». Here we follow the disclosure of personal experiences in the free flow of associations and the fear of repetition. 7 such reactions were recorded.

Some patients had an unusual reaction to words-stimuli, which can be manifested in grunting, complaints, exclamations, manifestations of autonomic emotions, the pronunciation of unnecessary or inappropriate word-reaction, etc., this is due to manifestations of psychological protection (according to Freud, the mechanism of resistance). This phenomenon relates to the thing that the word-stimulus associatively causes them unpleasant, associated with certain events, memories. The study identified 12 such reactions.

All this indicates a violation of the dynamics of thinking [9].

Thus, the peculiarities of the association of mentally healthy and mentally ill women differ in grammatical criteria and in the logic (content) of the connection between the word-stimulus and reactions. The free flow of associations reveals the personal experiences of the patients. In such a way, we can follow the process of disintegration of thinking, and, as a result, the speech of people with this type of mental illness.

Characteristics of speech in schizophrenia is a complex and ambiguous issue, the study of which should be done to facilitate the diagnosis of the disease. Further prospects of the study are related to the analysis of the peculiarities of speech and association in disorders of higher mental functions: Parkinson's disease, Alzheimer's disease, etc. 


\section{References:}

1. Белянин В. П. Психолингвистика : учебник. 4-е изд. Москва : Флинта : Московский психологосоциальный институт, 2007. 232 с.

2. Блейлер, Е. Руководство по психиатрии. Москва : Изд-во Независим. психиатр. ассоциации, 1993. 544 с.

3. Бук С. 3000 найчастотніших слів розмовно-побутового стилю сучасної української мови / наук. ред. Ф. С. Бацевич. Львів : ЛНУ імені Івана Франка, 2006. 180 с.

4. Вунд В. Введение в психологи. Москва : КомКнига, 2007. 168 с.

5. Засєліна Л. В. Вступ до психолінгвістики. Острог : Нац. універ. «Острозька академія», 2002. 168 с.

6. Иванов-Смоленский А. Г. Очерки патофизиологии высшей нервной деятельности: (По данным

И. П. Павлова и его школы). Москва : Медгиз, 1952. 296 с.

7. Ковалевська Т. Ю. Комунікативні аспекти нейролінгвістичного програмування. Одеса : Астропринт, $2008.344 \mathrm{c}$.

8. Лурия А. Р. Лекции по общей психологии. Санкт-Петербург : Питер, 2006. 320 с.

9. Лурия А. Р. Основные проблемы нейролингвистики. 3-е изд. Москва : Книжный дом ЛИБРОКОМ, 2009. $256 \mathrm{c}$.

10. Международная классификация болезней (10-й пересмотр). Санкт-Петербург : Изд. АДИС, 1994. 304 с.

11. Серкин В. П. Методы психологии, субъективной семантики и психосемантики : учебное пособие для вузов. Москва : Пчела, 2008. 382 с.

12. Случевский И. Ф. Атактическое мышление и шизофазия. Ленинград : Медицина, 1975. 160 с.

13. Терехова Д. І. Особливості сприйняття лексичної семантики слів: психолінгвістичний аспект : монографія. Київ : КДЛУ, 2000. 244 с.

14. Эббингауз Г., Бэн А. Ассоциативная психология. Москва: АСТ 1998. 544 с.

15. Юнг К. Г. Работы по психиатрии. Санкт-Петербург : Академический проект, 2000.

16. Юрьева Л. Н. Шизофрения: клиническое руководство для врачей. Днепропетровск : Новая идеология, 2010. 244 с.

17. American Psychiatric Association: Diagnostic and Statistical Manual of Mental Disorders, 5th edn. American Psychiatric Association, Washington, DC, 2013.

18. Bleuler E. Dementia praecox or the group of schizophrenia. New York : International Universities Press, 1911; English translation 1950.

19. Concise Medical Dictionary. Oxford University Press, 2010.

20. Freud S. (2016). A General Introduction to Psychoanalysis. Herts, Wordsworth Editions Ltd, 416 p.

21. Kraepelin E. Dementia praecox and paraphrenia. New York : Krieger, 1971 p.

\section{ЛокоТа І. М. АСОЩІЮВАННЯ ЯК ДІАГНОСТИЧНИЙ КРИТЕРІЙ ПАРАНОЇДНОЇ ШИЗОФРЕНІї}

Учені довели, що при шизофренії порушення виявляються на всіх рівнях організації мови: на фонетичному, семантичному та граматичному. Деякі рівні не тільки можуть слугувати для диференціації психічно хворих $і$ здорових людей, а й дають змогу відокремити пацієнтів із шизофренією від пацієнтів, які страждають на інші психічні захворювання, щзо й визначає необхідність поглибленого вивчення мовлення таких хворих і пояснення його глибинних психо- $і$ нейролінгвістичних механізмів, тісно пов'язаних із процесами асоціацій.

У статті описано результати асоиіативного експерименту, проведеного з особами, які мають діагноз «параноїдна шизофренія», $і$ психічно здоровими людьми. Метою статті $є$ виявлення особливостей асоиіативного фону людей, які мають діагноз «параноїдна шизофренія». Отримані реакиії класифіковано за логікою сполучення слів-стимулів і слів-реакиій (логічні та периферійні), а також за ̈̈х граматичними ознаками (синтагматичні й парадигматичні). Інтерпретацію отриманих результатів представлено поетапно. Здійснено порівняльний аналіз реакиій двох груп респондентів психічно хворих і здорових жінок.

Установлено, що особливості асоціювання психічно здорових і психічно хворих жінок відрізняються за граматичним критерієм і за логікою (змістом) зв 'язку слова-стимула та реакиій. Увільному потоиі асоиіачій розкриваються особистісні переживання хворих. Деякі хворі відмовилися брати участь в експерименті й мали незвичну реакиію на слова-стимули, що може виявлятися в буркотінні, скаргах, вигуках, проявах вегетативних емоцій, вимовлянні непотрібного чи недоречного слова-реакиії тощо.

Особливості мовлення при шизофренії є складним і неоднозначним питанням, вивченням якого варто займатися для полегшення діагностування хвороби. Подальші перспективи дослідження пов'язані з аналізом особливостей мовлення та асоціювання при порущенні вищих психічних функиій: хвороби Паркінсона, Альизеймера тощзо.

Ключові слова: шизофренія, параноїдна шизофренія, асоціації, асоціативний експеримент. 